\title{
Fantasy visions, Informal Urbanization, and Local conflict: Contradictions of Smart City imaginaries in India
}

Debadutta Parida ( $\sim$ dparida@ualberta.ca)

University of Alberta https://orcid.org/0000-0002-8439-1517

\section{Research Article}

Keywords: Smart Cities, Inclusive planning, EGT, Informality, Urban Governance, Urban Planning and Management

Posted Date: May 12th, 2021

DOI: https://doi.org/10.21203/rs.3.rs-496730/v1

License: (c) (i) This work is licensed under a Creative Commons Attribution 4.0 International License.

Read Full License 


\section{Abstract}

Smart city imaginaries have emerged in southern cities driven by neoliberal logics in the urban space. In the Indian context, much scholarly work in India has continued to engage with sweeping accounts of cities as opposed to detailed empirical studies. In this paper, I attempt to address this gap through an indepth ethnographic inquiry of a slum redevelopment project(part of Smart city initiative) in the city of Bhubaneswar, India. I seek to understand ways in which smart city initiatives influence the everyday life of the marginalized urban slum dwellers. Drawing on participant observation; document analysis; and semi-structured interviews, I put forth three key findings from the study that advance the notion that Smart Cities initiatives in Indian cities actively marginalize the slum dwellers by attempting to dominate through inclusion. I borrow from Foucauldian concept of 'counter-conducts' and its reimagination in planning by Huxley (2017) to demonstrate that smart cities discourses are counter-intuitively resulting in emergent spaces of resistance in the form of counter-hegemonic practices, thus allowing spaces for evolution of discourse from unfamiliar territories. I conclude by discussing that city planning and governance pathways in India risk creating complicated path dependencies that can lead to state-citizen conflicts in the future.

\section{Introduction}

Smart City initiatives are a dominant phenomenon in the urban context worldwide in the 21st century. In the urban discourse in India, Smart cities have assumed a centralized role in building futures of cities in India, triggered by regime change in the year 2014. Scholars have previously critiqued the 100 Smart Cities imaginary in India, terming it as a 'post-colonial utopian dream', driven by neoliberal logics and entrepreneurial interest in the city that has the potential to undermine democratic values (see Chakrabarty, 2018; Das, 2020; Datta, 2015a, 2015b; Watson, 2015). The relevant textual and visual perspectives and representations of smart city imaginaries across geographies have been extensively studied, documented, and examined across disciplines in theory (Hoelscher, 2016; Hollands, 2008; Kummitha \& Crutzen, 2017; Lindner \& Meissner, 2019; Prasad \& Alizadeh, 2020; Söderström, Paasche, \& Klauser, 2014).

Scholarly literature on smart cities initiatives in India however largely engages with the phenomenon rhetorically with sweeping accounts of cities in the 100 Smart cities list (such as studies by Datta, 2015b in Dholera, India). A key gap exists in terms of the lack of grassroots-based ethnographic accounts of knowledge and action related to the Smart City initiatives in Indian cities. This gap is acknowledged by Datta, (2015b) who notes that "the available tools of analysis... ...need to be complemented by ethnographic details on the everyday struggles faced by those at risk of being excluded from India's urban future."

In the above context, it is useful to re-examine what the smart city imaginary represents in the Indian city, and what it reveals and hides, and what future implications on planning and governance can be drawn from these understandings (Hollands, 2008). In this paper, I seek to understand the impact of smart city 
imaginaries (and their associated discourses and materializations) on the collective and political life of the informal residents in cities. I study how informal urban residents, especially slum dwellers negotiate the smart city plans and rhetoric that dominates the urban material and policy space in Indian cities. Through a year-long in-depth investigation of an in-situ slum redevelopment project, known as the Shantipally Slum Redevelopment Project (part of the Smart Cities Area Based Development Project) in Bhubaneswar city in Odisha, India, I examine the 'inclusive' smart governance in practice and the ensuing urban politics in the city.

The approach of 'documentation' as a strategy for critiquing has a scholarly tradition (based on Foucauldian ideals) in planning studies in other geographies, that can be traced to in-depth inductive studies by Flyvbjerg, (1998); Flyvbjerg \& Richardson, (2005); and Sharp \& Richardson, (2001). Smart city initiatives (such as local redevelopment projects that accompany the proposals) are a catalyst for fastpaced local changes to socio-spatial configurations in the city. These local area development projects are thus a significant site of inductive inquiry for planning and governance scholarship. Through a year-long ethnographic work in the city, I highlight how future goal dependencies in cities based on the smart imaginary are in direct conflict with existing institutional and governance processes and configurations, thus contributing to the reproduction of various forms of inequality (economic, socio-cultural, and political), and dehumanization of slum dwellers residing in informal spaces. As we delve deeper into local narratives and actions, the key ideas of 'digital or smart turn' in urban planning approaches in India seem contradictory and rather detrimental to the marginalized slum dwellers who are already at the margins of urban policy space in Bhubaneswar city.

In the rest of the paper, I elaborate on various aspects of the research. In Sect. 2, I present the theoretical framework for this paper, wherein I discuss the role of urban imaginaries in urban studies; and evolutionary approaches to understanding planning and governance systems. This is followed by a brief overview in Sect. 3, of the Smart Cities Mission, launched in 2015 in India. Section 4 deals with the methodological aspects of the study and introduced the case of a slum redevelopment project in Bhubaneswar city. In Sect. 5, I present three key findings from the case study, followed by a discussion of each finding in the context of present and future pathways of planning and governance systems in India. I conclude the paper in Sect. 6 with reflections on the theory, method, and findings; with some possibilities for future descriptive or normative work.

\section{Theoretical Framework}

In this section, I will briefly discuss two frames that guide the research work. First, the role of urban imaginaries as an emerging scholarly focus in planning and governance studies is discussed. This is followed by introducing the theoretical framework of the study - Evolutionary Governance Theory (EGT) and Co-Evolutionary Planning Theory. Both these theories are a post-structuralist take on planning and governance; taking into account the combination of social systems theory, and institutional approaches in cities. The core ideas of both theories are of co-evolution and contingency, significant concepts to see how forms of urban are emerging and changing themselves and why. These theories are used here due to 
their flexibility of use, without the baggage of rigid paradigmatic boundaries, thus making it a good starting point when exploring issues in southern cities such as those in India.

\subsection{Role of urban imaginaries in theory and practice}

Urban spaces are constituted by an open interplay of imaginations, discourses, and material spaces (Lindner \& Meissner, 2019). Urban imaginaries play a key role in the constant deconstruction and reconstruction of this interplay. I take up an interpretive approach in this study, thus assuming that all imaginaries are not merely a social construct, but are constantly re-created through interpretation from multiple frames by actors and institutions. I take a post-structuralist position that understands planning and governance as institutional frameworks that take into account history, cultures (institutional and forms of governance for example), and future imaginaries and desires (goals). Going beyond the materiality of space, imaginaries play a rather implicit part of every day (imagined and experienced) life in the urban (Çinar \& Bender, 2007). They range from visions of the future (smart cities, eco-cities, sustainable cities, resilient cities, and so forth); specific invocation of architecture motivated by a desire to seek attention towards a certain way of living in the future; to performative activism in the streets motivated by social and spatial justice. Imaginaries are conceptualized, experienced and performed simultaneously - and are significant point of inquiry for planning and governance scholars (Dunn, 2019; Laurian \& Inch, 2019; Lindner \& Meissner, 2019).

The role of imaginaries has been extensively studied across disciplines ever since social theory took a spatial turn (mostly due to exploration by scholars such as Henri Lefevbre, Michel Foucault, David Harvey, Doreen Massey, Edward Soja). Recent scholarship of relevance for this paper has focused on the intersections between urban imaginaries in practice with politics. Potter, (2020) presented the key links between urban imaginaries in practice with "neoliberal logics" of space. Similarly, Caprotti, (2019) and Adama, (2017) explored the role of smart imaginaries across geographies, both in the northern and southern context in advancing new and emergent forms of elite power. In general, contemporary urban imaginaries in emerging cities seem to be reinforcing exclusion, with the complicity of urban planning tools (Potter, 2020).

\subsection{Evolutionary approaches in Governance and Planning}

I draw ideas from Evolutionary Governance Theory (EGT) by Beunen et al., (2015), which provides a theoretical lens to understand co-evolution in the governance process from a comprehensive perspective. EGT considers coevolution as the central idea - a system is characterized by an ongoing system of change, in which existing structures are constantly at interplay, changing and shaping each other. Coevolution relies on the idea of iteration and recursive process, where several things co-evolve simultaneously or in different sequences, and result in new system configurations. In a system of governance, EGT assumes a complex interplay between actors and institutions (a/i); power and knowledge $(p / k)$; and discourses within a wider context of formal and informal ( $f /$ inf) institutional and pathways (that are influenced by path and goal dependencies). 
Actors here refer to individuals, groups, or organizations involved in the planning and governance process. Institutions are the planning and governance tools that make planning possible (such as master plans, policies, resilience plans, and zoning regulations). Institutions are created when actors interact and coordinate with each other. Actors and institutions do not exist in a vacuum but interact and coordinate within a complex system of discourses, that are constantly shaping and being shaped by each other. System here refers to functional systems such as governance systems, planning systems, the legal system, systems of democracy that exist through communication, and functional differentiation within a social system in the Luhmann-ian sense (Djanibekov \& Valentinov, 2015; Luhmann, 2004). Discourse refers to "an institutionalized way of talking that regulates and reinforces action" (Link, 1983). Planning systems thus can be imagined as complex, involving constant interaction, collisions, struggle, coalitions as well as temporal combinations, reconfigurations, and transformation between discourses and the resulting materializations. These complex interactions create new forms of power dynamics, flexibilities, and rigidities in the governance pathways, which are often difficult to change swiftly, which are known as path dependencies. Power dynamics and path dependencies influence which actors, institutions, and discourses are included or excluded in planning strategies.

The core ideas of EGT are borrowed into planning, presented as Co-evolutionary Planning Theory (Assche, Beunen, \& Duineveld, 2017) which is envisaged as being embedded within governance system; with the idea of contingency assuming central position - meaning that any existence of the system is a result of evolution, and it could have been different. Using this lens, it is then possible to understand governance and planning systems evolving out of older governance and planning systems, and in a constant state of flux (since other systems around which these systems are loosely coupled, are also evolving). Many studies have used EGT to understand governance processes and structures within particular contexts, studying why particular planning approaches are successful in certain (and unsuccessful in other), what theories they implicitly assume and obscure, and to what extent various elements (a/l; p/k and f/inf) are contingent (Assche et al., 2015; Djanibekov \& Valentinov, 2015; Schlüter et al., 2020; Vries \& Aalvanger, 2015). In this study, the slum redevelopment project in Bhubaneswar city is understood using an evolutionary lens, to understand multiple interpretations at play at the local level related to the materialization of smart city initiatives as city scale. EGT is used here since it is flexible and compatible with the use of multiple approaches, theories, and concepts across disciplines. In this paper, I use the EGT lens to critique the local planning approaches of the smart cities initiative, along with other concepts in planning and governance (described further in Sect. 5).

\section{Smart Cities Initiatives In India: A Brief Overview}

The Smart Cities Mission is a central government initiative in India, launched in the year 2015, triggered by regime change. The Mission is reflective of a rather suddenly emergent paradigm shift in India's planning and development policy response to increasing levels of urbanization (Pathak, 2020; Praharaj, Han, \& Hawken, 2018). The mission aims to make a hundred cities 'smart'; wherein the cities were selected in five phases based on a state-level competitive application-based format that included the municipal performance of infrastructure services and utilities. The mission is broadly based on a 
combination of institutional structures and urban-design-based approaches in planning along with ideas of systems thinking relying on multiple scales of governance. There are four main components - Areabased developments of particular city areas based on retrofitting and redevelopment projects; urban renewal projects; affordable housing for the urban poor; and pan-city development projects that involve 'smart' technological interventions into existing infrastructure. The projects are carried out through the creation of a new institution (a combination of different state and non-state actors) called Special Purpose Vehicles (SPV) at the municipal level. As of 2015, 98 cities were selected in the Smart cities list, while seven cities have withdrawn in the past years.

The Smart Cities initiative has had its share of critiques in academic as well as practice. Key issues identified by scholars are related to ambiguity in its conceptualization (Praharaj et al., 2018); too much focus on technological aspects of the city while ignoring long term vision, cultural setting, governance, and policy issues (Harris, 2015; Parida, 2020; Prasad \& Alizadeh, 2020); inadequate attention on policy integration matters (Praharaj et al., 2018). Other scholars have attempted to understand the smart cities mission from an evolutionary perspective. Hoelscher, (2016) studied the evolving national discourses in India, suggesting that despite the increase in clarity over the conceptualization of the concept and approaches towards policy integration, the chances of success of the vision remains uncertain. Prasad \& Alizadeh, (2020) studied the evolving concept of smart cities across multiple cities through comparative policy analysis. They advanced the discourse by Hoelscher, (2016) by claiming that the national discourse has gradually evolved by having governance, citizen and infrastructure dimensions take centre stage in smart city policy making. However, both studies maintain that empirical work needs to be carried out to support these analytical work on smart cities in Indian cities.

\section{Data And Methods}

\subsection{Setting, data collection, and analysis}

I employ a qualitative methodological framework in this paper based on the case study method (Flyvbjerg, 2006; Ruddin, 2006; Yin, 2009, 2012). I draw on year-long ethnographic fieldwork in Bhubaneswar city in India drawing upon participant observation; document analysis; and semi-structured interviews of slum dwellers who are at risk of eviction, professional city planners, slum activists, and representatives, elected political leaders, municipal officials, academicians, and local non-governmental organizations. The unit of analysis for the study is a slum redevelopment project as part of the Smart City Proposal in Bhubaneswar, which is currently active and has resulted in local conflict among the slum residents and the state. In total, I conducted fourteen interviews at various times within the previous year (between June 2019 and March 2021). The interview questions were based on various actors'

perspectives and interpretation of the Smart city discourse; how the materialization of specific projects as part of the Smart city proposal is affecting (or changing) the socio-political life of the slum dwellers; and how they are responding to those external changes. 
Owing to the ongoing restrictions around the Covid-19 pandemic, most interviews (eleven out of fourteen) were conducted through phone conversations and online platforms, keeping in mind all ethical considerations and with due consent. The identities of all interviewees were kept confidential, by storing them safely with access only to the authors, as well as by encrypting their original names to unique codes.

All interviews were transcribed and coded using the NVIVO software. During the writing process, few repeat interviews were focused on validating the key findings that are presented here. Most interviews lasted between 45-75 minutes while following up interviews lasted nearly 20-30 minutes. All interviews were transcribed and the relevant identified narratives were coded using descriptive, thematic, and thematic codes using the NVIVO software. The key documents analyzed were media articles relevant to Smart City-related actions in Bhubaneswar city, case laws related to legal conflict between slum residents and the state, and Smart City proposal-related documents of the city.

\subsection{Case study: Shantipally Slum Redevelopment Project, Bhubaneswar}

As described earlier, the inquiry was conducted in the city of Bhubaneswar, Odisha. Bhubaneswar city was the first in the top twenty cities that were selected in the Smart City Mission in India. The city had a population of 0.84 million in 2011, with a decadal growth of 27.74 percent, which makes it one of the fastest-growing cities in India. The city has nearly 0.16 million residents (close to one-fifth population) living in slums (Anand \& Deb, 2017). As part of its Smart City Proposal in 2015, Bhubaneswar city proposed city-wide (intelligent transit systems, parking management, emergency management, and other technological interventions to city utilities and services) and local-scaled interventions (Bhubaneswar Town Centre District or BTCD as the key area-based development).

The BTCD comprises multiple projects, mostly infrastructural such as street improvements through urban design interventions, parks, housing, slum redevelopment, and social infrastructure. A key part of the BTCD is the 'Shanti Nagar Awas Yojana' or locally called the Shantipally Slum Redevelopment Project, in which nearly 2232 dwellings are proposed in an area of 10 acres (with a proposed investment of nearly 150 crores involving a public-private partnership model where the state is facilitator). The slum redevelopment project is ongoing currently and assumes to provide housing to nearly 2000 households in nearby slums. One of the slums, 'Shantipally basti' (comprises nearly 1200 households) which is close to the ongoing housing project, is at immediate risk of eviction due to the redevelopment project. The slum has existed in the city for nearly four decades, has undergone rapid growth in the last decade. While negotiations are on between the state and the residents for over a year, nearly 200 households in the slum have resorted to judicial pleas to stop the 'forced displacement' to the proposed housing due to numerous reasons. The ongoing tension, and the ensuing political and media attention around it make it an interesting case to study and theorize about the impact of materialization of 'smart' imaginaries and discourses in the Indian urban space.

\section{Key Findings And Discussion}


In this section, I present three key findings from the study in separate dealing with a relevant conversation within planning and governance of smart cities in India. Each of the three sections is related to a question that will help us understand the notions of discursive planning across geographies and scale, complex inter-dependencies between informal processes and governance, and 'counter-conducts' as a significant response to neoliberal technologies of dominance in India. I discuss the three findings and observations in light of various scholarly works within urban planning, and their implications on future planning and governance pathways in Indian cities embarking upon a journey to achieve 'smart'-ness.

\subsection{Discursive creation of 'smart neighborhoods' as a desired object of imagination}

My analysis reaffirms the discourse that the Smart City initiative is a direct result of hegemonic middleclass discourses in tandem with neoliberal calls for an entrepreneurial city that are based on an urban imaginary that is oriented towards urban spaces in cities in the global north. In this context, I contend that middle-class complacency (and often complicity) create demand for 'smart' neighborhoods in cities in India. The Smart City initiative in Indian cities, when conceptualized and problematized from this perspective, no longer remains just a politically neutral 'social construct' but rather an active neoliberal project that is inspired by shifting the urban discourse of the past decades.

This is contributed by the elitist tendencies of urban planning in India. One of the interviewees (an activist) described the neoliberal state planning apparatus as follows:

The (state) government keeps telling that there is not enough land to provide for spatial needs of slum dwellers in the city. We brought many issues in RTI. They gave 50 acres' land to DLF company to build elite apartments. Why? xxxx University (name withheld) got 150 acres' land and other private institutes have got also. They are selling land and making money. Why can't they provide land to slum dwellers as per their needs?

The role of market forces enabling the changing discourse is clear, as revealed by one of the interviewees (an urban planner) when probed about the complex relationship between urbanization, urban informality in Bhubaneswar city:

The fact that we are stuck in informality is one of the big problems. We allow those people to stay there thinking where will they go. We forget that the law is same for everyone. I know they have nowhere to go, but still they are sitting there illegally. If you take hard legal action, then humanitarian organizations will come and be sitting and doing dharnas, that you cannot evict those people. The slums in Acharya Vihar, Kalinga Institute and Salia Sahi (neighborhoods in Bhubaneswar city) are absolutely not tenable. Who will regularize them?

Such problematization is problematic in itself since it enables the evolving discourse around informal housing from being a housing problem (in the planning discourse) towards being illegal objects in the city space that can no longer be tolerated or untenable (invoking a legal discourse). The 'smart' imaginary also assumes implicitly that smart neighborhoods are superior, and hence are a sign of positive change in the Indian urban space. These discourses create a demand for 'Smart' governance frameworks that easily privilege the urban middle class, real-estate developers, and the social elite while marginalizing the 
slum dwellers further by questioning their legal citizenship and legitimacy while using local scaled law enforcement and structural violence (see similar findings by Das, 2020; and Datta, 2015b).

The state discourses on urban planning, in general, have evolved in the past two decades, from a state bureaucratic-centered approach towards being more responsive towards the global discourses on inequality. As a result, recent imaginaries such as smart cities, and the resulting discourses, at least rhetorically, have created room for a will to creating 'inclusive' spaces in the local area retrofit plans. Yet, the materialization of these plans remains highly problematic. I add to the ongoing conversation in planning about the implications of using 'inclusion' as a core principle in communicative planning, by arguing that the current smart city imaginary in India has a central desire to 'dominate through inclusion' (first articulated by Miraftab, 2009). This idea relates with previous critics of using participatory methods in planning in the northern cities when there are a power imbalance and permanence of conflict between state and certain non-state actors (Hillier, 2003; Kothari \& Cooke, 2001; Ngwenya \& Cirolia, 2020; Satgé \& Watson, 2018; Watson, 2006). At the same time, inclusion as a concept remains popular in planning theory practice in India, since it helps obscure other important discourses of resistance that are witnessed in the cities every day.

\subsection{Smart cities, informality, and augmented marginalization}

Further analysis on how the smart city initiative influences the everyday existence in the city led me to focus on the notions of governance of the marginalized groups (in this case, slum dwellers) in Bhubaneswar city. I find that apart from marginalizing the slum dwellers through rhetoric, the process of materialization of the 'smart' neighborhood formation in Bhubaneswar city is resulting in the forced displacement and conflict within the city space between the slum dwellers and the state. This contributes towards the increasing vulnerability of the city slum dwellers who find themselves far away from the new imaginary and the resulting discursive formation of the 'legitimate smart citizen'. On the ground, many slum dwellers and slum activities highlighted how the forced displacement is negatively affecting their socio-political networks and legitimacy in the city. In this context, the smart imaginaries are in direct conflict with the existing informal nature of urbanization that dominates the material landscape in cities. An interviewee (slum resident and activist) highlighted the precarity of slum dwellers in the Shantipally basti:

The government has created transit houses which are like vending zones (too small to reside in). They come directly on the evening before the day of eviction and give us notice to shift there. Then next day they come will their bulldozers to evict us. We have stayed here for over four decades; how can they simply throw us out.

The role of citizens' relationship with power (through political patronage) is key in the ensuing success or failure of local planning projects in Indian cities. In the case of Shantipally Basti, residents described how they continue to use political patronage as a key strategy to delay the smart city project. A respondent (slum activist) reflected how power and politics play out at the local scale in the city, and how this is linked with the vulnerability of the residents: 
Slum dwellers are forced to support the ruling party; else they are targeted by evictions. Slum-dwellers have their insecurities - financial, physical; at the heart of their insecurity is lack of tenured land. When probed further, another interviewee (slum dweller) claimed:

In Shantipally basti, there are 1200 houses - containing supporters of BJD, BJP, Congress, CPI, me and another activist (name withheld). BJD households want to take a house by being displaced, BJP supporting households are in complete opposition to the redevelopment project. Our position is that we need land in the same location and not flats. This has led to conflicts between people. When the BDA goes for eviction, everybody forgets these internal differences and gets together.

Thus, a complex interplay of slum dwellers' vulnerabilities on one hand and conflicting rationalities within the groups has resulted in a culture of mistrust in the city and contributes to the prevalence of conflict. This is giving rise to what I call augmented marginalization, wherein the formal policies of the state are contributing actively and materially towards economic, socio-cultural, and political marginalization of the slum dwellers through weakening livelihoods, loosening social networks and identity in the city, as well as forced conflicts between residents.

A wider conversation in planning theory and practice of equal importance is the general (and problematic) assumption of formal and informal systems in cities i.e. a formal state and informal citizens. Some scholars have attempted to theorize the notion of informality from multiple aspects such as a 'way of life' (Alsayyad, 2004); informal spaces as places of hope (Correa, 1988); and focus on formal-informal dialectics (M. Pathak \& Mahadevia, 2018; Schindler, 2014; Tonkiss, 2012; Watson, 2009). Yet, while the focus on informality as a bottom-up process and context is focused, the technologies of informal governance are rather under-theorized and lack empirical specificity and context (few studies have explored this Roy, 2009; Schindler, 2017). I add to the ongoing theorization of informality by arguing that the relationship between informality and governance is more nuanced than is generally observed. This is influenced by Foucauldian perspectives in planning that see things beyond black and white, progressive and regressive, and embrace the idea that there are always different rationalities at work within the wider regimes of discourses, actors, institutions, and forms of knowledge (Flyvbjerg, 1998; Huxley, 2017). All forms of governance rely on some degree of informal methods and techniques to achieve formal goals, as demonstrated in the actions of the local government in this section. The actions such as state actors explicitly coercing the slum dwellers, while actively flouting regulatory norms themselves during the eviction process shows that informality is not stable, but constantly evolving and temporal. In this context, all actors involved in the urban process resort to being highly strategic; and it is useful to understand the governance process as a combination of centrality and marginality, and the permanence of informality as a process as well as context (Assche, Beunen, \& Duineveld, 2013; Beunen et al., 2015; Schlüter et al., 2020).

\subsection{Counter-conducts and the struggle for legitimacy}

Almost counter-intuitively, one of the key findings from the study was that smart cities initiatives are resulting in a gradual emergence of insurgent practices (in the form of counter-hegemonic practices) to counter the elite-driven smart imaginary in Bhubaneswar city. The affected slum dwellers balance their 
actions by holding on to political linkages to attain 'formal' citizenship status in the city while engaging actively in counter-hegemonic practices (through a range of anti-eviction strategies) against represented by the smart city discourse. This is different from the earlier observation regarding political patronage, in terms of the timescale of action. The counter-hegemonic strategies are short-term in nature, focused on immediate survival needs as well as delaying the inevitable. These actions are further balanced by longterm actions based on the slum dwellers' desire to achieve formality first, to achieve legitimacy in the urban space later - an alternate imaginary based on livelihood needs and political expediencies.

The counter-hegemonic practices range from formal practices (such as formal protests, negotiations with local leaders, and judicial appeals), and informal practices (ranging from leveraging political patronage to negotiate a better deal with state actors, especially during elections to plain refusal). An interviewee (slum activist) described:

We use a range of actions to deal with evictions. We mostly take help of RTI (Right to Information), court appeals, demonstration while other times also engage with direct dialogue with the MLA and MP (politicians).

Another resident described:

We want the government to give us proper documents and not just verbal assurances. Most of all, we need land-not these small ones, but at least 400 square feet. Also, we need it near our workplace. They want to give us land in Chandaka (a forest land on the outskirts of the city). How will we survive there? No, we will not go there.

Conversely, state action to deal with slum dwellers' grassroots actions also has changed from explicit violent eviction drives in the past towards subtler strategies such as the use of legal tools to achieve the state's desire to make the city 'smart'. A respondent (slum resident and activist) described:

The BDA keeps coming for evictions, and we keep fighting them. In 2017, this government introduced a new guideline, that rehabilitation won't be done in urban areas, due to land shortage. The government uses this to carry out evictions

I connect these plain refusals by the slum dwellers to 'counter-conducts', a Foucauldian concept of forms of constant struggle against the processes by the state to govern the conduct of the 'subject' or the 'other' by the slum-dwellers against an initiative that is designed to marginalize them (Foucault, 2007; Huxley, 2017). Counter-conducts are 'stubborn refusals of forms of state power' (Huxley, 2017), and pose significant questions on specific forms of governance, while providing useful tools on "how not to be governed like that, in the name of principles, with such and such an objective in mind..." (Foucault, 2007). These counter-conducts do not exist independently but arise in interplay with governmentality (productive power of governance structures that produce 'subjects' to maintain the 'other'). In the present context, taking an evolutionary perspective, I further contend that in cities, counter-conducts in the form of counter-hegemonic practices by slum dwellers in Bhubaneswar city do not simply arise out of state action, but co-evolve with it. The key guiding principles for counter-conducts are two key elements strategy and balance; and temporality. The former constantly question the evolving formal-informal 
institutions and spaces in the city, while the latter is more adaptive and pragmatic (focuses on something that simply works for the moment rather). The constant evolving governance structure with space for counter-conduct is difficult to grasp, even more difficult to practice, yet cannot and should not be simply avoided. Governance structures that do not have space for force and counter-force can undermine democracy, while the existence of space may lead to the permanence of conflict.

\section{Concluding Thoughts}

In this paper, I set out to understand how the smart imaginaries in India are a key guiding force to the creation of discursive objects of desire, that promote certain forms of local-scaled materialization of the same with significant consequences for the present and the future. The hegemonic discourses accompanied by 'smart' imaginaries are attempting to build neighborhoods that reproduce and reify the existing historically exclusionary planning pathways, often relying on violence and informal governance means such as deregulations (as described by Roy, 2005, 2009). In this context, planning pathways run the risk of creating complicated path dependencies (for example, new forms of conflicts may arise between tenured slum dwellers and the state related to livelihood and legitimacy in the city) that may lead to further state-citizen conflicts in the future. While in rhetoric, the Smart city proposal in Bhubaneswar city claims to be inclusive of slum dwellers' rights and livelihood; yet what is observed from this local case is that the planning process adopted for the materialization of the same is highly contradictory.

Counter-intuitively, the speedy nature of conflict has given rise to new spaces for grassroots mobilization and counter-conducts among historically marginalized groups, which has so far been able to use formal and informal channels strategically and temporally to delay state-led evictions that accompany the smart city initiative. These narratives are mostly motivated by a desire to attain short-term survival, mediumterm formality, and long-term legitimacy within the urban space. Further to this, thinking from an evolutionary perspective (EGT lens) suggests that the Shantipally redevelopment project shows a classic case of the dangers of goal and path dependency in India's current development trends, risking investment lock-ins for municipalities, conflicts across scales and geographies, and a culture of mistrust among actors in the urban material and policy space. These developments can negatively affect the social, cultural, and political identity of the marginalized groups in future governance pathways in the long term.

This paper has three main scholarly contributions. First, I provide empirical advances through ethnographic work at a local scale on the nature of materialization of smart city imaginary and accompanying discourse in Indian cities. This work creates a base that can be built on with further work to create a large body of scholarly work that critiques India's smart cities movement from the bottom-up. Second, I provide an evolutionary lens to understand India's Smart Cities Mission that is constantly coevolving along with other actors, institutions, discourses, narratives, political structures, and urban governance processes. Although the use of EGT lens in the southern context is still in a nascent stage, this paper can help create a solid foundation for further work that helps understand governance systems as dynamic creations that embrace the idea of informality rather than think of it as a 'static' issue to be 
either problematized or romanticized. Third, I explore the usefulness of counter-conducts as a useful concept to describe discourses and actions of resistance by the marginalized groups in Indian cities, as a key response to the dominance of smart city projects. Counter-conducts help illuminate the exercise of power in cities; and have the potential to become a valuable concept in planning theory, when used through appropriate transversals across geographies. Future work can involve further in-depth ethnographic work on the smart cities initiatives in Indian cities, that cut across multiple disciplines, and attempt to provide different ways to understand and theorize urban politics in the global south.

\section{Declarations}

\section{Funding}

No funding was acquired for the study.

\section{Conflict of Interest}

The author declares no conflict of interest.

\section{Availability of data}

The data used in the study is mostly drawn from semi-structured interviews. It is confidential, yet some aspects of coding and analysis can be provided if requested.

\section{Ethics and consent}

All participants in the study provided their consent to participate, and be allowed to be interviewed, as well as their words to be used in this article in quotes. All ethical guidelines were followed in line with the University of Alberta's REB.

\section{References}

Adama, O. (2017). Urban imaginaries: funding mega infrastructure projects in Lagos, Nigeria. GeoJournal, 83, 257-274. https://doi.org/10.1007/s10708-016-9761-8

Alsayyad, N. (2004). Urban Informality as a "New" Way of Life. In Urban Informality: Transnational perspectives from the Middle East, Latin America, and South Asia.

Anand, G., \& Deb, A. (2017). Planning "Violations", and Urban Inclusion: A Study of Bhubaneswar. IIHS. New Delhi.

Assche, K. Van, Beunen, R., \& Duineveld, M. (2013). Formal / informal dialectics and the selftransformation of spatial planning systems, 1-21. https://doi.org/10.1177/0095399712469194 
Assche, K. Van, Beunen, R., \& Duineveld, M. (2015). An Overview of EGT's Main Concepts. In R. Beunen, K. Van Assche, \& M. Duineveld (Eds.), Evolutionary Governance Theory:Theory and Applications. Springer.

Assche, K. Van, Beunen, R., \& Duineveld, M. (2017). Co-evolutionary Planning Theory Evolutionary Governance Theory and Its Relatives. In M. Gunder, A. Madanipour, \& V. Watson (Eds.), The Routledge Handbook of Planning Theory (pp. 221-233). Routledge.

Beunen, R., Assche, K. Van, \& Duineveld, M. (2015). Evolutionary Governance Theory. (R. Beunen, K. Van Assche, \& M. Duineveld, Eds.), Evolutionary Governance Theory. Springer. https://doi.org/10.1007/978-3319-12274-8

Caprotti, F. (2019). Spaces of visibility in the smart city: Flagship urban spaces and the smart urban imaginary. Urban Studies, 56(12), 2465-2479. https://doi.org/10.1177/0042098018798597

Chakrabarty, A. (2018). Smart mischief : an attempt to demystify the Smart Cities craze in India. Environment \& Urbanization, 31(1), 193-208. https://doi.org/10.1177/0956247818769234

Çinar, A., \& Bender, T. (2007). Urban Imaginaries: Locating the Modern City. University of Minnesota Press.

Correa, C. (1988). The New Landscape: Urbanisation in the Third World.

Das, D. (2020). In pursuit of being smart? A critical analysis of India's s smart cities endeavor. Urban Geography, 41(1), 55-78. https://doi.org/10.1080/02723638.2019.1646049

Datta, A. (2015a). A 100 smart cities, a 100 utopias. Dialogues in Human Geography, 5(1), 49-53. https://doi.org/10.1177/2043820614565750

Datta, A. (2015b). New urban utopias of postcolonial India: ' Entrepreneurial urbanization ' in Dholera smart city, Gujarat. Dialogues in Human Geography, 5(1), 3-22.

https://doi.org/10.1177/2043820614565748

Djanibekov, N., \& Valentinov, V. (2015). Evolutionary Governance, Sustainability, and Systems Theory: The Case of Central Asia. In R. Beunen, K. Van Assche, \& M. Duineveld (Eds.), Evolutionary Governance Theory: Theory and Applications. Springer.

Dunn, N. (2019). Urban Imaginaries and the Palimpsest of the future. In M. Meissner \& C. Lindner (Eds.), The Routledge Companion to Urban Imaginaries (pp. 375-386). Routledge.

Flyvbjerg, B. (1998). Rationality and Power. University of Chicago Press.

Flyvbjerg, B. (2006). Five Misunderstandings about Case-Study Research. Qualitative Inquiry, 12(2), 219245. https://doi.org/10.1177/1077800405284363

Flyvbjerg, B., \& Richardson, T. (2005). Planning and Foucault: In search of the dark side of planning theory. In P. Allmendinger \& M. Tewdwr-Jones (Eds.), Planning Futures: New Directions for Planning 
Theory.

Foucault, M. (2007). 'What is critique?' In S. Lotringer (Ed.), The Politics of Truth. Los Angeles: Semiotext(e).

Harris, A. (2015). Smart ventures in Modi's urban India. Dialogues in Human Geography, 5(1), 23-26. https://doi.org/10.1177/2043820614565865

Hillier, J. (2003). 'Agon'izing over Consensus: Why Habermasian ideals cannot be "Real." Planning Theory, 2(1), 37-59.

Hoelscher, K. (2016). The evolution of the smart cities agenda in India. International Area Studies Review, 19(1), 28-44. https://doi.org/10.1177/2233865916632089

Hollands, R. G. (2008). Will the real smart city please stand up? City, 12(3), 303-320.

https://doi.org/10.1080/13604810802479126

Huxley, M. (2017). COUNTERING ' THE DARK SIDE' OF PLANNING Power, Governmentality, CounterConduct. In M. Gunder, A. Madanipour, \& V. Watson (Eds.), The Routledge Handbook of Planning Theory (pp. 207-220). Routledge.

Kothari, V., \& Cooke, B. (2001). Participation: The New Tyranny. London ZED books.

Kummitha, R. K. R., \& Crutzen, N. (2017). How do we understand smart cities? An evolutionary perspective. Cities, 67(March), 43-52. https://doi.org/10.1016/j.cities.2017.04.010

Laurian, L., \& Inch, A. (2019). On-Time and Planning: Opening Futures by Cultivating a "Sense of Now ." Journal of Planning Literature, 34(3), 267-285. https://doi.org/10.1177/0885412218817775

Lindner, C., \& Meissner, M. (2019). Introduction: urban imaginaries in theory and practice. In C. Lindner \& M. Meissner (Eds.), The Routledge Companion to Urban Imaginaries (pp. 1-22). New York: Routledge.

Link, J. (1983). Was ist und was bringt Diskurstaktik. KulturRRevolution, 2, 60-66.

Luhmann, N. (2004). Law as a social system. Oxford: Oxford University Press.

Miraftab, F. (2009). Insurgent Planning: Situating Radical Planning in the Global South. Planning Theory, 8(1), 32-50. https://doi.org/10.1177/1473095208099297

Ngwenya, N., \& Cirolia, L. R. (2020). Conflicts Between and Within: The 'Conflicting Rationalities' of Informal Occupation in South Africa. Planning Theory and Practice, 00(00), 1-16.

https://doi.org/10.1080/14649357.2020.1808237

Parida, D. (2020). God Is In The Market: Is City Planning In India Getting Hijacked By Free-Market Overtures? Urban Voices. Retrieved from https://urbanvoices.in/city-planning-in-free-market/ 
Pathak, C. R. (2020). Challenges of Smart Cities in India. In S. Bandyopadhyay, C. R. Pathak, \& T. P. Dentinho (Eds.), Urbanization and Regional Sustainability in South Asia (pp. 261-270).

Pathak, M., \& Mahadevia, D. (2018). Urban Informality and Planning: Challenges to Mainstreaming Resilience in Indian Cities. In Y. A. S. Yamagata (Ed.), Resilience-Oriented Urban Planning: Theoretical and Empirical Insights.

Potter, E. (2020). Contesting imaginaries in the Australian city: Urban planning, public storytelling and the implications for climate change. Urban Studies, 57(7), 1536-1552.

https://doi.org/10.1177/0042098018821304

Praharaj, S., Han, J. H., \& Hawken, S. (2018). City, Culture and Society Urban innovation through policy integration: Critical perspectives from 100 smart cities mission in India. City, Culture and Society, 12(January 2017), 35-43. https://doi.org/10.1016/j.ccs.2017.06.004

Prasad, D., \& Alizadeh, T. (2020). What Makes Indian Cities Smart? A Policy Analysis of Smart Cities Mission. Telematics and Informatics, 55(January), 101466. https://doi.org/10.1016/j.tele.2020.101466

Roy, A. (2005). Urban informality: Toward an epistemology of planning. Journal of the American Planning Association, 71(2), 147-158. https://doi.org/10.1080/01944360508976689

Roy, A. (2009). Why India cannot plan its cities: Informality, insurgence, and the idiom of urbanization. Planning Theory, 8(1), 76-87. https://doi.org/10.1177/1473095208099299

Ruddin, L. P. (2006). You Can Generalize Stupid! Social Scientists, Bent Flyvbjerg, and Case Study Methodology. Qualitative Inquiry, 12(4), 797-812.

Satgé, R. de, \& Watson, V. (2018). Urban Planning in the Global South: Conflicting Rationalities in Contested Urban Space. Urban Planning in the Global South. https://doi.org/10.1007/978-3-319-69496-2

Schindler, S. (2014). Producing and contesting the formal/informal divide: Regulating street hawking in Delhi, India, 51(12), 2596-2612. https://doi.org/10.1177/0042098013510566

Schindler, S. (2017). Beyond a state-centric approach to urban informality: Interactions between Delhi's middle class and the informal service sector. Current Sociology, 65(2), 248-259.

https://doi.org/10.1177/0011392116657296

Schlüter, A., Assche, K. Van, Hornidge, A., \& Vaidianu, N. (2020). Land-sea interactions and coastal development: An evolutionary governance perspective. Marine Policy, 112. https://doi.org/10.1016/j.marpol.2019.103801

Sharp, L. I. Z., \& Richardson, T. I. M. (2001). Reflections on Foucauldian Discourse Analysis in Planning and Environmental Policy Research, 209(August 2000), 193-209. 
Söderström, O., Paasche, T., \& Klauser, F. (2014). Smart cities as corporate storytelling. City, 18(3), 307320. https://doi.org/10.1080/13604813.2014.906716

Tonkiss, F. (2012). Informality and Its Discontents. In M. Angélil \& R. Hehl (Eds.), Informalize!: Essays on the Political Economy of Urban Form (pp. 55-70). Berlin: Ruby Press.

Vries, J. de, \& Aalvanger, A. (2015). Negotiating Differences: The Role of Social Identity in the Emergence of Institutions for Local Governance. In R. Beunen, K. Van Assche, \& M. Duineveld (Eds.), Evolutionary Governance Theory: Theory and Applications. Springer.

Watson, V. (2006). Deep difference: Diversity, planning, and ethics. Planning Theory, 5(1), 31-50. https://doi.org/10.1177/1473095206061020

Watson, V. (2009). Seeing from the South: Refocusing urban planning on the globe's central urban issues. Urban Studies, 46(11), 2259-2275. https://doi.org/10.1177/0042098009342598

Watson, V. (2015). The allure of 'smart city ' rhetoric: India and Africa. Dialogues in Human Geography, 5(1), 36-39. https://doi.org/10.1177/2043820614565868

Yin, R. K. (2009). Case study research and applications: design and methods (Fifth Edit).

Yin, R. K. (2012). Applications of Case Study Research. SAGE Publications, Inc. 